\title{
ATTITUDE ANALYSIS ON THE EFFECT OF CAREER DEVELOPMENT ON ORGANIZATIONAL COMMITMENT OF FRONTLINE EMPLOYEES OF BANKING SECTOR IN MATARAM CITY
}

\author{
Allamu M. Rogib Rova*, Student \\ Asmony Thatok, Sulaimiah, Lecturers \\ Graduate Program in Management, Mataram University, Indonesia \\ *E-mail: rogibrova@gmail.com \\ ORCID: 0000-0002-2502-9032
}

\begin{abstract}
This research aimed to determine and analyze partially and simultaneously the effect of career development based on education, training, mutation and promotion on organizational commitment of frontline employees of banking sector in Mataram City. This research was a causal-associative research that aimed to analyze the correlation between one variable with other variables or how a variable affects other variables. Population of the research was frontline employees of banks that were state-owned companies in Mataram City amounted to 188 people. The samples of 65 people were obtained by using the Slovin formula. By using proportional random sampling technique, the distributed respondents of $\mathrm{BNI}$ amounted to 30 people, BTN amounted to 6 people and Bank Mandiri amounted to 29 people. The data analysis was performed by using multiple linear regressions. The analysis results showed that the variables of education, training, mutation and promotion positively and significantly affected the organizational commitment of frontline employees of banking sector in Mataram City. In addition, partially, the analysis results showed that the variables of education, training, mutation and promotion had positive and significant effect on organizational commitment of frontline employees of banking sector in Mataram City respectively.
\end{abstract}

\section{KEY WORDS}

Career development, education, training, mutation, promotion, organizational commitment.

The high flow of money circulation in the globalization era and the free trade have made the banking sector as the most strategic sector in trade because the function of the bank as an intermediary has shown an important role in trade and development. Completeness of bank services can be seen from several aspects of the bank's capabilities in terms of capital, facilities, and human resources it owns. Regarding to services produced by human resource competence, it cannot be separated from the frontline role that directly intersects with the customers or consumers. To be a reliable front liner, training and intensive development are required. In addition to the interests of the organization, this training and development activities are supported by Bank Indonesia Regulation no 5/14/PBI/2003.

The existence of career development is also required by every employee to improve work commitment of human resources. Safiri (2015) stated that companies are still trying to build employee loyalty through effective human resources implementation including career planning and development. Jakson et al. (2009) mentioned that training and development can provide a shared experience that enhances understanding among employees of diverse backgrounds and helps to accelerate the development of company cohesion and employee commitment. Hans (2007) stated that career development has a direct effect on human resource commitments. Developed organizations are identical to career development. Career development plays an important role in improving employee commitment to achieve the goals of an organization or company.

Furthermore, the employee's belief in career development will bring consequences to his/her commitment for the company. Employees who believe in their career development positively tend to have a high level of commitment, thereby avoiding them from various 
attitudes and work behaviors that hinder the achievement of organizational goals, such as strikes, absenteeism and turnover. It may indicate that the employee has a high commitment. Conversely, employees who believe their career development negatively tend to have a low level of commitment.

In fact, following career development program for a front liner is not easy. Various process stages must be passed by a front liner to be able to follow the process of career development. The selection process that must be passed depends on the working system of the bank. In addition to performance-oriented, to be able to follow a career development program, a bank's front liner will be examined from the age, employment, educational background, gender, marital status, number of dependents, and rewards from the concerned front liner, and other technical matters. The most basic thing is that a career development program in a banking system is based on the needs of the bank; on the extent to which front liner employees must be trained, educated, and prepared to support the movement of the bank in order to achieve the organizational goals.

Due to the commitment of frontline banking employees, on the average, frontline employees have high commitment. It is despite the career development program that is implemented by a bank. It can be seen from the process of front liner service to the customers that always be based on the applicable SOP, and can also be seen from the front liner behavior in avoiding strikes. However, in reality, not all front liners have an opportunity to develop their careers and not a few front liner employees who do not follow a career development program and retire in the same position.

Companies, which are engaged in services, especially the banking sector, are very imperative in fostering their employees because the company's success in achieving the goals is strongly affected by the success of the employees in providing services. If the frontline employees perceive their career development positively, they will have more commitment to the company.

Previous Relevant Research. Previous relevant research that had been conducted showed the relationship between career development and the improvement of organizational commitment. Hutagalung (2015) found a direct effect of career development consisting of education, training, mutation and promotion on organizational commitment. Moreover, Putra (2014) found that the dominant effect of career development variables consisting of education, training, mutation and promotion had direct effect to organizational commitment. A research conducted by Oktariandini (2015) showed a positive correlation between career development variable consisting of education, training, mutation and promotion and organizational commitment variable. This research showed the attachment of career development on commitment of $32.3 \%$. Furthermore, Adryan (2012) found that career development based on education and training variables had more dominant effect on organizational commitment compared with mutation and promotion variables.

Previous research conducted by Pratistiani (2013) found that education and training variables had significant effect on organizational commitment. Hidayat (2015) found a positive correlation of career development consisting of education and training on the improvement of organizational commitment. Furthermore, Subhi (2014) found that education and training consisting of instructor skills, training materials, training methods, and training tools had an effect on organizational commitment simultaneously. Meanwhile, it partially indicated that the instructor skills, training materials and training tools had an effect on organizational commitment whereas training method had no effect on organizational commitment. Furthermore, Mudaim (2014) argued that career development based on rotation/mutation and training played a role in improving organizational commitment. Salindeho (2016) proved that career development based on mutation and promotion had direct and indirect effects on organizational commitment. It was supported by the research findings of Wibowo (2006) stating that career development, one of which consisted of promotion had positive and significant effect on organizational commitment. Then Safitri (2015) found a positive correlation between career development consisting of training and promotion and organizational commitment. 
Previous relevant research indicated that there was no effect between career development and organizational commitment that had been proven by Hidayah (2015). Furthermore, Halimah (2013) in her findings showed that there was no direct effect on career development towards organizational commitment. Sari (2010) showed that career development program had negative but insignificant effect on organizational commitment.

Based on previous relevant research and theoretical framework, the following hypotheses can be formulated:

$\mathrm{H} 1$ : Career development based on education, training, mutation and promotion has positive and significant effect simultaneously on organizational commitment of the employees.

$\mathrm{H} 2$ : Career development based on education has positive and significant effect on organizational commitment of the employees.

H3: Career development based on training has positive and significant effect on organizational commitment of the employees.

H4: Career development based on mutation has positive and significant effect on organizational commitment of the employees.

H5: Career development based on promotion has positive and significant effect on organizational commitment of the employees.
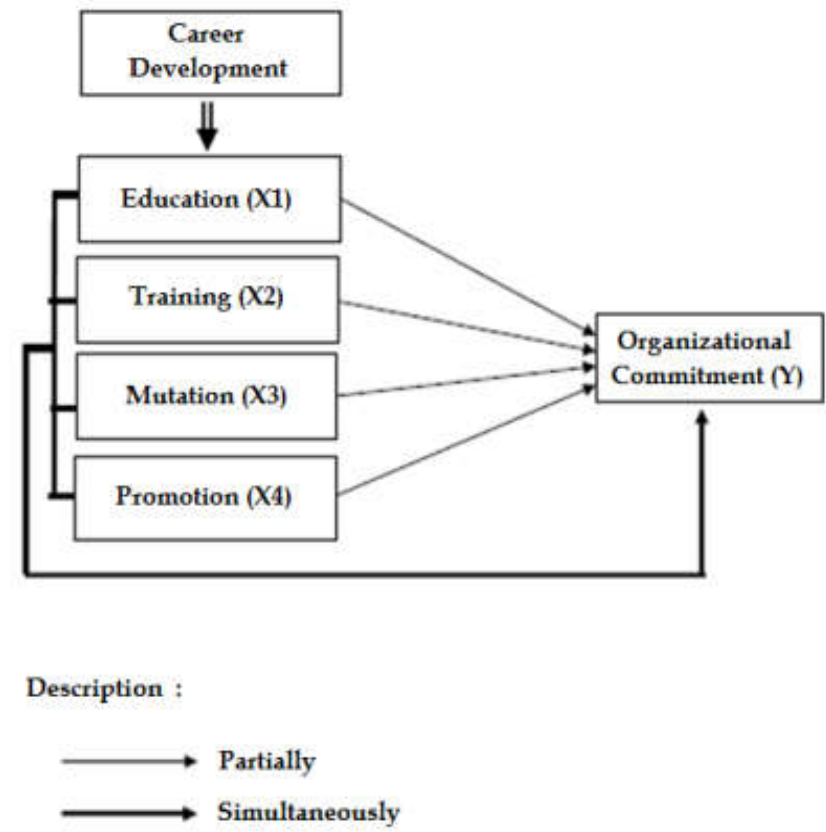

Figure 1 - Conceptual Framework of the Research

\section{METHODS OF RESEARCH}

This research applied quantitative approach. This was a type of causal associative research that aimed to determine the effect of independent variables on the dependent variable. This research was conducted in banking with state-owned company status consisting of BNI, BTN, and Bank Mandiri. BRI was not included because its frontline employees were contract employees. The involved respondents of frontline employees were as many as 65 people. The distributed questionnaires were as many as 65 questionnaires which then all the questionnaires were processed to obtain the results of the respondents' answers. The variables of this research were career development which included education quoted from Adryan (2012), training from Hutagalung (2015), mutation and promotion from Hidayat (2015), and organizational commitment from Hidayat (2015).

Scaling on each variable applied a five-level scale (Likert scale) consisting of highly appropriate, appropriate, sufficient, inappropriate, and highly inappropriate. The result of reliability test of the research instrument showed that all items in the research variables were 
reliable because the Cronbach's Alpha was above 0.244 . Meanwhile, the result of validity test of the research instrument by using correlation technique of Pearson Product Moment showed that the items on all variables were valid because the value of $t$-calculate was more than 0.244 . The data analysis of this research was performed by using SPSS 16 program.

\section{RESULTS AND DISCUSSION}

According to the hypotheses that have been formulated previously, multiple linear regression analysis was used to predict how much effect of career development variable consisting of education, training, mutation and promotion on organizational commitment of frontline banking employee in Mataram City. in Eq. (1):

Based on the calculation result, the regression equation was obtained as can be seen

$$
Y=7.198+0.45 X 1+0.569 X 2+0.204 X 3+0.249 X 4
$$

Table 1 - Output Results of Multiple Linear Regressions

\begin{tabular}{lllll}
\hline Variables & Coefficient Estimate & Beta & T & Sig. \\
\hline Organizational Commitment (Y) & 7.198 & & & \\
Education (X1) & 0.45 & 0.224 & 2.186 & 0.033 \\
Training (X2) & 0.569 & 0.320 & 2.973 & 0.004 \\
Mutation (X3) & 0.204 & 0.233 & 2.421 & 0.019 \\
Promotion (X4) & 0.249 & 0.244 & 2.562 & 0.013 \\
F Calculate & 18.654 & & & \\
Adjust R R $^{2}$ & 0.525 & & &
\end{tabular}

Based on Table 1, the adjusted $\mathrm{R}$ square was 0.525 . It meant that career development variable including education (X1), training (X2), mutation (X3) and promotion (X4) had effect on organizational commitment $(Y)$ as many as $52.5 \%$. Meanwhile, the rest $100 \%-52.5 \%=$ $47.5 \%$ was influenced by other factors that were not examined in this research. From the regression equation, it could be interpreted as follows:

- The regression coefficient value of 7.198 showed that if education, training, mutation and promotion in a constant condition or $\mathrm{X}=0$, organizational commitment of banking frontline employees in Mataram City was equal to 7.198.

- X1 (education) had the regression coefficient value of 0.45 and had positive effect on $Y$ (organizational commitment). It meant that if the education of frontline employees was better and increased by 1 unit with the assumption that other variables were constant then it could increase the organizational commitment of frontline employee of banking sector in Mataram City as many as 0.45 .

- X2 (training) had the regression coefficient value of 0.569 and had positive effect on $Y$ (organizational commitment). It meant that if the training of frontline employees was better and increased by 1 unit with the assumption that other variables were constant then it could increase the organizational commitment of frontline employee of banking sector in Mataram City as many as 0.569 .

- X3 (mutation) had the regression coefficient value of 0.204 and had positive effect on $Y$ (organizational commitment). It meant that if the mutation of frontline employees was better and increased by 1 unit with the assumption that other variables were constant then it could increase the organizational commitment of frontline employee of banking sector in Mataram City as many as 0.204 .

- X4 (promotion) had the regression coefficient value of 0.249 and had positive effect on $\mathrm{Y}$ (organizational commitment). It meant that if the promotion of frontline employees was better and increased by 1 unit with the assumption that other variables were constant then it could increase the organizational commitment of frontline employee of banking sector in Mataram City as many as 0.249.

The processing results of $F$ test for the hypotheses using SPSS 16.0 application with significance level of $(\alpha) 0.05(n=65)$ were presented in Table 2. 
Table 2 - The Results of ANOVA Output in Regression Analysis

ANOVA $^{\mathrm{b}}$

\begin{tabular}{|c|c|c|c|c|c|c|}
\hline \multicolumn{2}{|c|}{ Model } & Sum of Squares & $\mathrm{df}$ & Mean Square & $\mathrm{F}$ & Sig. \\
\hline \multirow[t]{2}{*}{1} & Regression & 704.929 & 4 & 176.232 & 18.654 & $.000^{\mathrm{a}}$ \\
\hline & Residual & $\begin{array}{l}566.855 \\
1271785\end{array}$ & 60 & 9.448 & & \\
\hline
\end{tabular}

a. Predictors: (Constant), Promotion, Education, Training, Mutation

b. Dependent Variable: Organizational Commitment

Conventional testing criteria at $\alpha=5 \%=0.05$ with $\mathrm{df}=\mathrm{k} ;(\mathrm{n}-\mathrm{k}-1)=4 ;(65-4-1)=4 ; 60$ then F-table $=2.53$ and F-calculate $=18.654$. Due to F-calculate $>\mathrm{F}$-table, then $\mathrm{HO}$ was rejected and $\mathrm{Ha}$ was accepted so that the variables of education, training, mutation, and promotion had significant effect simultaneously on organizational commitment. The test criteria used the probability of significance value $=0.000$ or $0.0 \%$ less than $5 \%$ then $\mathrm{H} 0$ was rejected and $\mathrm{Ha}$ was accepted so that the variables of education, training, mutation and promotion had significant effect on organizational commitment.

The results of $t$ test process are presented in Table 3.

Table 3 - The Results of t-test

Coefficients $^{a}$

\begin{tabular}{lccccc}
\hline \multirow{2}{*}{ Model } & \multicolumn{2}{c}{ Unstandardized Coefficients } & Standardized Coefficients & \multirow{2}{*}{ S } & Sig. \\
\cline { 2 - 3 } & $\mathrm{B}$ & Std. Error & & 1.444 & .154 \\
\hline (Constant) & 7.198 & 4.984 & .224 & 2.186 & .033 \\
Education & .450 & .206 & .320 & 2.973 & .004 \\
1 Training & .569 & .191 & .233 & 2.421 & .019 \\
Mutation & .204 & .084 & .244 & 2.562 & .013 \\
Promotion & .249 & .097 & & & \\
\hline
\end{tabular}

a. Dependent Variable: Organizational Commitment

This test was conducted to determine whether or not independent variables significantly had effect on dependent variable.

- Education Variable: Conventional test criterion found that at the error level $\alpha=0.025$ (two-tailed test) with $\mathrm{df}=60(65-4-1)$, it was known that $\mathrm{t}$-table $=2.00$ and $\mathrm{t}$-calculate $=$ 2.186. Due to t-calculate > t-table, then education variable (X1) had significant effect on organizational commitment of frontline employees of banking sector in Mataram City which means that $\mathrm{HO}$ was rejected and $\mathrm{Ha}$ was accepted. Based on the test criterion, by looking at the probability of the significance value $=0.033$ or $3.3 \%$ which was smaller than $5 \%$ then $\mathrm{H} 0$ was rejected and Ha was accepted. Thus, it could be concluded that the education variable (X1) had significant effect on organizational commitment of frontline employees of banking sector in Mataram City.

- Training Variable: Conventional test criterion found that at the error level $\alpha=0.025$ (two-tailed test) with $\mathrm{df}=60(65-4-1)$, it was known that $\mathrm{t}$-table $=2.00$ and $\mathrm{t}$-calculate $=$ 2.973. Due to $t$-calculate $>$ t-table, then training variable $(X 2)$ had significant effect on organizational commitment of frontline employees of banking sector in Mataram City which means that $\mathrm{HO}$ was rejected and $\mathrm{Ha}$ was accepted. Based on the test criterion, by looking at the probability of the significance value $=0.004$ or $0.4 \%$ which was smaller than $5 \%$ then $\mathrm{H} 0$ was rejected and $\mathrm{Ha}$ was accepted. Thus, it could be concluded that the training variable (X2) had significant effect on organizational commitment of frontline employees of banking sector in Mataram City.

- Mutation Variable: Conventional test criterion found that at the error level $\alpha=0.025$ (two-tailed test) with $\mathrm{df}=60(65-4-1)$, it was known that $\mathrm{t}$-table $=2.00$ and $\mathrm{t}$-calculate $=$ 2.421. Due to t-calculate $>$ t-table, then mutation variable $(X 3)$ had significant effect on organizational commitment of frontline employees of banking sector in Mataram City which means that $\mathrm{HO}$ was rejected and $\mathrm{Ha}$ was accepted. Based on the test criterion, by looking at 
the probability of the significance value $=0.019$ or $1.9 \%$ which was smaller than $5 \%$ then $\mathrm{H} 0$ was rejected and $\mathrm{Ha}$ was accepted. Thus, it could be concluded that the mutation variable (X3) had significant effect on organizational commitment of frontline employees of banking sector in Mataram City.

- Promotion Variable: Conventional test criterion found that at the error level $\alpha=0.025$ (two-tailed test) with $\mathrm{df}=60(65-4-1)$, it was known that $\mathrm{t}$-table $=2.00$ and $\mathrm{t}$-calculate $=$ 2.562. Due to t-calculate $>$ t-table, then promotion variable $(X 4)$ had significant effect on organizational commitment of frontline employees of banking sector in Mataram City which means that $\mathrm{HO}$ was rejected and $\mathrm{Ha}$ was accepted. Based on the test criterion, by looking at the probability of the significance value $=0.013$ or $1.3 \%$ which was smaller than $5 \%$ then $\mathrm{H} 0$ was rejected and $\mathrm{Ha}$ was accepted. Thus, it could be concluded that the promotion variable (X4) had significant effect on organizational commitment of frontline employees of banking sector in Mataram City.

Hypothesis 1: The result of hypotheses testing showed that career development based on education, training, mutation and promotion had positive and significant effect on organizational commitment of frontline employees of banking sector in Mataram City simultaneously. It meant that the higher the employee's perception of career development (education, training, mutation, and promotion) the higher the employee's organizational commitment, and the lower the employee's perception of career development, the lower the employee's organizational commitment.

Banking companies or other organizations in Mataram City describe career development as a management strategy of human resource used to attract the talented people to be interested and willing to work and devote their competence to work for the organization. Career development is carried out so that the employees can continue to work in the organization for long periods of time or even their entire working period is devoted to the organization. Career development in such a way may have effect on employees' commitment to their career positively.

These findings were consistent with Hutagalung's (2015) research who found a direct positive effect in career development consisting of education, training, mutation and promotion on organizational commitment. In addition, Putra (2014) also found the dominant effect of career development variable consisting of education, training, mutation and promotion that had an effect on organizational commitment directly. A research conducted by Oktariandini (2015) showed a positive correlation between career development variable consisting of education, training, mutation and promotion and organizational commitment variable. This research showed the attachment of career development on commitment of $32.3 \%$. Furthermore, Adryan (2012) found that career development based on education and training variables had more dominant effect on organizational commitment compared with mutation and promotion variables.

The proposed hypotheses, that had been proven, indicated that the perception of career development might have effect on organizational commitment of an employee to his/her company. If an employee had a positive perception to the opportunities given by the company, their commitment to the company would increase. Due to this positive perception, the employees would feel that the company provided them with opportunities to develop themselves, clear career paths, career planning and deployment at employment levels in accordance with their skills, and better job opportunities according to their ability and potential.

One of the benefits of career development is to direct employee's actions to the goals set by the company, which can lead the employees to be involved in achieving those goals. Ultimately, such engagement is also an element of organizational commitment.

Hypothesis 2: The results of hypothesis testing showed that career development based on education partially had positive and significant effect on the organizational commitment of frontline employees of banking sector in Mataram City. It meant that the higher the employee's perception of career development based on education then it would increase employee's commitment to the company and this increase occurred significantly. On the 
other hand, low perception of career development based on education would significantly lead to lower organizational commitment.

Phoobe and Steband in Adryan (2012) stated that there was a positive correlation between education and the increased organizational commitment of the employees. Previous research conducted by Pratistiani (2013) found that education variables had significant effect on organizational commitment. Armawati (2016), Hidayat (2015), Hutagalung (2015), Putra (2014), Oktariandini (2015), and Subhi (2014) found direct effect of career development based on education on organizational commitment. Furthermore, Adryan (2012) found that career development based on education had dominant effect on organizational commitment.

Based on the findings of this research, it could be interpreted that if banking companies in Mataram City provide opportunities to improve the educational background of frontline employees, pay attention to educational level, adjust employee's career with their disciplines, improve their competences, and prepare frontline employees for future tasks, then it will have positive and significant effect on the organizational commitment of the frontline employees.

Hypothesis 3: The results of hypothesis testing showed that career development based on training partially had positive and significant effect on the organizational commitment of frontline employees of banking sector in Mataram City. It meant that the higher the employee's perception of career development based on training then it would increase employee's commitment to the company and this increase occurred significantly. On the other hand, low perception of career development based on training would significantly lead to lower organizational commitment.

Previous research conducted by Pratistiani (2013) found that training had significant effect on organizational commitment. Armawati (2016), Hutagalung (2015), Subhi (2014), Putra (2014), Oktariandini (2015), and Safitri (2015) found that career development based on training had effect on organizational commitment. Furthermore, Mudaim (2014) and Hidayat (2015) revealed that career development based on training played a role in increasing organizational commitment. Adryan (2012) found that career development based on training had more dominant effect on organizational commitment than other variables.

Based on the findings of this research, it could be interpreted that if the banking companies in Mataram City provide skill training to frontline employees, the suitability between the training and the implementation of the task, the ease of training process, the instructor skills and the training program that can facilitate the completion of the work, then it will have positive and significant effect on the organizational commitment of frontline employees.

Hypothesis 4: The results of hypothesis testing showed that career development based on mutation partially had positive and significant effect on the organizational commitment of frontline employees of banking sector in Mataram City. It meant that the higher the employee's perception of career development based on mutation then it would increase employee's commitment to the company and this increase occurred significantly. On the other hand, low perception of career development based on mutation would significantly lead to lower organizational commitment.

Armawati (2016), Hutagalung (2015), Putra (2014), Oktariandini (2015), and Adryan (2012) found that career development based on mutations had direct effect on organizational commitment. Furthermore, Mudaim (2014) argued that career development based on mutation or rotation played a role in increasing organizational commitment. Salindeho (2016) proved that career development based on mutation had direct and indirect effect on organizational commitment.

Based on the findings of this research, it could be interpreted that if the banking companies in Mataram City mutate the frontline employee by paying attention to the mutation period, be objective in doing the mutation, pay attention to mutation limit, pay attention to the ability or competence of the mutated employee, make the discipline level as mutation assessment, pay attention to the mutation implementation and requirements, socialize the mutation, pay attention to the assessment and justice in the mutation process, and if the employees can anticipate the mutation, then it will have positive and significant effect on the organizational commitment of the frontline employees. 
Hypothesis 5: The results of hypothesis testing showed that career development based on promotion partially had positive and significant effect on the organizational commitment of frontline employees of banking sector in Mataram City. It meant that the higher the employee's perception of career development based on promotion then it would increase employee's commitment to the company and this increase occurred significantly. On the other hand, low perception of career development based on promotion would significantly lead to lower organizational commitment of the employees to the company.

Promotion conducted within the scope of the organization also plays a role in increasing organizational commitment of the employees. Armawati (2016), Hutagalung (2015), Putra (2014), Oktariandini (2015), and Adryan (2012) found direct effect of career development based on promotion on organizational commitment. Salindeho (2016) proved that career development based on promotion had direct and indirect effect on organizational commitment. That was also supported by the research findings conducted by Wibowo (2006) who stated that career development, one of which consisted of promotion, had positive and significant effect on organizational commitment. In addition, Safitri (2015) found a positive correlation between career development based on promotion and organizational commitment. Based on the findings of this research, it could be interpreted that if the banking companies in Mataram City promotes the position of the frontline employees by paying attention to the working period, competence, insurance and clear career atmosphere for frontline employees, skill, thoroughness and fairness in promotion process, it will have a positive effect and will significantly increase the organizational commitment of frontline employee.

\section{CONCLUSION}

Based on the findings of the research conducted simultaneously (thoroughly), it was found that there was a significant effect of career development based on education, training, mutation and promotion on organizational commitment of frontline employees. Partially, career development based on education had significant effect on organizational commitment, career development based on training had significant effect on organizational commitment, career development based on mutation had significant effect on organizational commitment, and career development based on promotion had significant effect on organizational commitment.

There were several limitations in this research including: this research was limited to career development variable based on education, training, mutation and promotion as well as organizational commitment variable. In addition, this research only examined the frontline employees of the banking sector without including the bank employees as a whole and this research only included 65 respondents. The next limitation of the research was the researchers only examined employees who work in the banking sector with the status of state-owned company in Mataram City. Thus, the limitations of the circumstances experienced by employees working only in those banks certainly cannot represent the condition of banking employees in Mataram City as a whole which has different policies for its employees.

Having the limitations in conducting this research, the researchers expect that future research, related to career development and organizational commitment variables, further extends the scope of the research, such as setting, population, sample, work sector and so on. It will certainly strengthen the theories and findings of previous researchers related to these variables. Furthermore, regarding to frontline employees, future researchers are expected to raise other topics or variables according to the characteristics of the employees themselves which tend to have a productive age and the majority of the employees are fresh graduates. The researcher may further extend the scope of the research object which is not limited to frontline employees but includes the entire employee position in the banking sector. In addition, future researchers can conduct comparative research that examine more in depth about career development in the banking sector by comparing career development in Private Banks with State-Owned Banks. 


\section{REFERENCES}

1. Adryan, A. (2012). Analisis Pengaruh Pengembangan Karir Organisasi terhadap Komitmen Karyawan pada Kantor Pusat PT. Bank Sulselbar Kota Makasar. Makasar: Fakultas Ekonomi dan Bisnis Universitas Hasanuddin.

2. Armawati, D. (2016). Pengaruh Pengembangan Karir terhadap Komitmen Organisasi (Kasus Karyawan PT. Panin Bank Kantor Cabang Pekanbaru. JOM FISIP, 3(1).

3. Halimah, R. (2013). Pengaruh gaya kepemimpinan dan pengembangan karir terhadap kepuasan kerja dan komitmen organisasi Pegawai Negeri Sipil Sekretariat Jenderal MPR RI. Retrieved from http://lib.ui.ac.id/.

4. Hans, J. (2007). Human Resources Management, (Edisi Kesembilan). New Jersey: Upper Saddle River, Prentice Hall.

5. Hidayah, A. (2015). Analisis Pengembangan Karir, Budaya Organisasi, terhadap Komitmen Organisasional dengan Kepuasan Kerja sebagai Intervening pada Pegawai UP3AD se-Koordinator Pati. Kudus: Magister Manajemen Fakultas Ekonomi Universitas Muria Kudus.

6. Hidayat, A. S. (2015). Pengaruh Kompensasi dan Pengembangan Karir terhadap Komitmen Organisasi (Studi Kasus pada PT. Bank BRI Syariah Cabang Bandung Suniaraja). Jurnal Ecodemica, 3(1).

7. Hutagalung, L Y. B. (2015). Pengaruh Iklim Kerja dan Pengembangan Karir Terhadap Komitmen Organisasi dan Kepuasan Kerja Karyawan pada Kantor Pusat PDAM Tirtanadi Provinsi Sumatera Utara. Medan: Fakultas Ekonomi dan Bisnis Universitas Sumatera Utara.

8. Jakson, S. E., Schuler, R. S., \& Werner, S. (2009). Pengelolaan Sumber Daya Manusia, (Edisi 10 - Buku 2), Translated by Prihartono Benny. Jakarta: Penerbit Salemba Empat.

9. Mudaim. (2014). Peran Persepsi Pengembangan Karir dan Dukngan Organisasi terhadap Komitmen Organisasi (Penelitian terhadap Perawat Badan Pelayanan Kesehatan Rumah Sakit Daerah "Mardi Waluyo" Blitar Jawa Timur. Lampung: Universitas Muhammadiyah Metro.

10. Oktariandini, N. R. (2015). Pengaruh Pengembangan Karir Organisasi terhadap Komitmen Perawat pada Rumah Sakit Umum DR. Hasan Sadikin Bandung. Retrieved from http://repository.widyatama.ac.id.

11. Pratistiani, D. A. (2013). Pengaruh Diklat dan Iklim Organisasi terhadap Komitmen Organisasi serta Kinerja Karyawan pada Koperasi Agribisnis Trautama Nusantara Jember. Jember: Perpustakaan Universitas Jember.

12. Putra, F. D. (2014). Analisis Pengaruh Kompensasi, Pengembangan Karir, dan Lingkungan Kerja Non Fisik terhadap Komitmen Organisasional. Semarang: Fakultas Ekonomi dan Bisnis Universitas Diponegoro.

13. Safitri, W. C. (2015). Hubungan Antara Persepsi Terhadap Pengembangan Karir dengan Komitmen Organisasi pada Karyawan Rumah Sakit. Surakarta: Fakultas Psikologi Universitas Muhammadiyah Surakarta.

14. Salindeho, C. L. (2016). Analisis Pengaruh Iklim Kerja dan Pengembangan Karir terhadap Komitmen Karir dengan Kepuasan Kerja sebagai Variabel Intervening. Jurnal Riset Bisnis dan Manajemen, 4(3), 303-318.

15. Sari, A.W. (2010). Pengaruh Faktor - Faktor yang berkaitan dengan Karir terhadap Komitmen Organisasi. Surakarta: Magister Manajemen Universitas Muhammadiyah Surakarta.

16. Subhi, Z. (2014). Pengaruh Pendidikan dan Pelatihan Terhadap Komitmen Organisasional Pegawai Pada Dinas Pendapatan, Pengelolaan Keuangan dan Aset Daerah Kabupaten Kapuas Hulu. Jakarta: Perpustakaan Universitas Terbuka.

17. Wibowo, F. D. (2006). Analisis Pengaruh Peran Kepemimpinan dan Pengembangan Karir terhadap Komitmen Organisasi dalam meningkatkan Kinerja Karyawan. Semarang: Program Pasca Sarjana Universitas Diponegoro. 